\title{
Traduzir a Relação das línguas: uma conversa com Édouard Glissant
}

\section{Traduire la Relation des langues : un entretien avec Édouard Glissant}

\author{
Tradução, apresentação e notas de Henrique Provinzano \\ Amaral ${ }^{1}$
}

\section{Apresentação}

Esta entrevista, até agora inédita em português, foi concedida pelo escritor e pensador martinicano Édouard Glissant (1928 - 2011) à jovem pesquisadora italiana Luigia Pattano, em 2010, tendo sido originalmente publicada na Trickster - Rivista online di studi Interculturali. Em agosto de 2011, seis meses após a morte do entrevistado, foi reproduzida à guisa de homenagem na plataforma virtual Mondes francophones, onde se encontra disponível ${ }^{2}$. Trata-se, assim, de uma das derradeiras conversas com esse teórico fundamental - tanto para os estudos culturalistas e decoloniais, como para as abordagens das poéticas antilhanas e outras áreas do conhecimento -, que em 2009 havia publicado o último de seus principais ensaios, Philosophie de la Relation. Poésie en étendue (2009). No entanto, o foco do diálogo não incide especificamente sobre esse livro, nem sobre os numerosos lançamentos de

\footnotetext{
1 Doutorando em Letras Estrangeiras e Tradução pela FFLCH-USP, com pesquisa sobre o pensamento tradutório de Édouard Glissant. E-mail para contato: henrique.provinzano.amaral@usp.br . O presente trabalho foi realizado com apoio da Coordenação de Aperfeiçoamento de Pessoal de Nível Superior - Brasil (CAPES) - Código de financiamento 001. This study was financed in part by the Coordenação de Aperfeiçoamento de Pessoal de Nível Superior - Brasil (CAPES) - Finance Code 001. Também agradeço ao Prof. Dr. Álvaro Faleiros, pela revisão da tradução e por algumas sugestões preciosas às notas de rodapé.

2 Link: https://mondesfrancophones.com/dossiers/edouard-glissant/traduire-la-relation-deslangues-un-entretien-avec-edouard-glissant/. Acesso em 02/03/2021.
} 
Glissant naquele ano de $2010^{3}$, mas sobre um tema pouco explorado em sua obra ensaística: a tradução.

Com efeito, a preocupação teórica com a tradução emerge no pensamento glissantiano, de maneira descontínua e tardia, a partir da década de 1990. Em 1994, é objeto de duas breves exposições em eventos acadêmicos, depois compiladas em volumes de anais ${ }^{4}$; no ano seguinte, um desses discursos é abreviado e incorporado, com modificações, às páginas finais da segunda conferência de Introduction à une poétique du divers [Glissant, 1995b; Introdução a uma poética da diversidade, 2005a]; dez anos mais tarde, o tema é novamente abordado numa breve seção do ensaio La Cohée du Lamentin [2005b; O pensamento do tremor - La Cohée du Lamentin, 2014]. Desse modo, apesar do caráter fragmentário, é visível que a reflexão tradutória atravessa a porção final da ensaística glissantiana, inscrevendo-se entre os lugares delineados e frequentados por sua vasta topologia teórica.

Os últimos e mais extensos desdobramentos de tal reflexão estão reunidos justamente nesta conversa - e a escolha deste termo para traduzir a palavra francesa "entretien" está longe de ser fortuita. Num primeiro sentido, porque Glissant parece evitar o desenvolvimento convencional, explicativo, que é de se esperar numa entrevista voltada para um assunto particular. Não obstante as tentativas de Pattano no sentido de relacionar, em positivo ou em negativo, seu pensamento tradutório a certas reflexões incontornáveis do campo dos Estudos da Tradução - representadas, aqui, sobretudo pelos escritos de Walter Benjamin, Paul Ricoeur e Antoine Berman -, Glissant mostra-se quase irredutível, recusando de modo taxativo qualquer princípio de filiação.

\footnotetext{
${ }^{3}$ Trata-se do breve ensaio 10 mai. Mémoires de la traite négrière, de l'esclavage et de leurs abolitions (Glissant, 2010a), da coletânea de entrevistas L'imaginaire des langues. Entretiens avec Lise Gauvin (1989-2009) (2010b) e da antologia poética La terre, le feu, l'eau et les vents. Une anthologie de la poésie du Tout-Monde (2010c), esta última organizada e apresentada por Glissant.

${ }^{4}$ São as exposições "Traduire: relire, relier (Conférence inaugurale)" (Glissant, 1995a) e "Les nouvelles données de l'écriture" (Glissant, 1997a). O corpus dos textos glissantianos sobre tradução foi estabelecido por Catherine Delpech-Hellsten (ITM), em 2014, e se encontra disponível para download neste endereço: https://www.tout-monde.com/sites/cathydelpech---corpus-glissantien.pdf. Acesso em 24/03/2021.
} 
Num segundo sentido, as idas e vindas do discurso, as repetições ou redundâncias, as evasivas ou tergiversações, e mesmo certa postura reticente do indagado consistem tanto num estratagema para escapar a algumas das perguntas insistentes daquela que indaga, como numa tentativa manifesta de conduzir a dinâmica da entrevista para aquela da conversa. Isso se torna explícito na parte final, em que Glissant converte sua própria estrutura em objeto do debate. Com isso, penso, ele pretende trazer à tona as características de um discurso calcado numa compreensão particular da oralidade caribenha e inspirado na arte dos contadores crioulos ("conteurs créoles"), que fazia uso expressivo daqueles procedimentos ${ }^{5}$. Dessa maneira, a própria tessitura da conversa aparenta replicar, talvez à revelia das intenções da pesquisadora, alguns aspectos marcantes do pensamento glissantiano - entre eles, a recusa de uma clareza expositiva excessiva, vista como uma das tentações universalizantes das epistemologias ocidentais, e a consequente defesa do “direito à opacidade" (Glissant, 2011, p. 184).

O saldo é, sem dúvidas, positivo. Apesar - ou, antes, por causa - das hesitações, dos desvios, dos imprevistos, das frases profusas ou lacônicas, esta conversa com Édouard Glissant se revela um dos principais mananciais teóricocríticos para adentrar sua reflexão tradutória, em especial no que diz respeito às articulações desta com a proposta de um pensamento ensaístico, antidogmático e intensamente atual, desenvolvido sob o signo da Relação.

\section{Introdução de Luigia Pattano}

A tradução, essa arte da aproximação, ou melhor, da reconciliação e do tocar levemente, tão crucial em toda e qualquer disciplina, e no entanto tão subestimada e facilmente criticável em sua prática, ocupa um lugar cada vez mais importante no Ocidente, nas reflexões desenvolvidas no seio das chamadas Ciências Humanas. Semelhante centralidade se explica, de um lado, pelo fato de que a tradução permite interrogar sobre a natureza da linguagem enquanto

\footnotetext{
${ }^{5}$ Para uma análise mais detida do tema da oralidade, ou do oral, na obra glissantiana, em especial no ensaio Poétique de la Relation, remeto a minha dissertação de mestrado (Amaral, 2019).
} 
competência universal do humano, uma competência que é confrontada à (ou talvez desmentida pela) pluralidade de suas realizações concretas, histórica, geográfica e socialmente determinadas. De outro lado, essa centralidade também se explica pelo fato de que a tradução, prática do encontro em que se negocia continuamente 0 nexo ${ }^{6}$ com o Outro, oferece uma perspectiva promissora para abordar a questão da identidade. O texto traduzido é, com efeito, o lugar próprio desse encontro, um lugar bastante arriscado, já que é tão fácil se perder nele (pelas cópias inconscientes, pelos contrassensos despercebidos, pelos mal-entendidos linguísticos) quanto perder de vista o Outro pelas práticas mais ou menos conscientes de dominação ego ou etnocêntrica (como, por exemplo, a sobretradução, a normalização e a explicitação $\left.{ }^{7}\right)$.

Entre os pensadores contemporâneos mais eminentes que se debruçam, ou se debruçaram, sobre os desafios teóricos da tradução, figura Édouard Glissant. Escritor martinicano a quem devemos a elaboração de uma Poética da Relação em que se entrelaçam a filosofia e a poesia, e que não se pretende absolutamente um sistema de pensamento, Glissant sempre se interessou pelas questões de linguagem. Desde o início, seu trabalho teórico se caracteriza, de fato, por uma insistência em distinguir as noções de "língua" e de "linguagem" que não tem nada de saussuriano - essa última se dando a entender, no Discours Antillais (Glissant, 1981, p. 236), como “uma prática comum, para uma dada

\footnotetext{
${ }^{6}$ No original, "rapport". Busquei, sobretudo na tradução das falas de Glissant, utilizar "relação"/"Relação" somente nas ocorrências de "relation"/"Relation", para evitar a banalização desse termo central para o desenvolvimento dos argumentos. Há uma alternância, no texto da conversa, entre ocorrências dessa noção com inicial maiúscula e minúscula, o que costuma ser evitado nos ensaios glissantianos, justamente para que possamos identificar quanto se trata do sentido geral e da categoria de pensamento específica.

${ }^{7}$ Aqui, a autora parece ter em mente, sobretudo, "a analítica da tradução e a sistemática da deformação" proposta por Berman em A tradução e a letra ou o albergue do longínquo (2007 [1991]). A "sobretradução" ("surtraduction"), também conhecida em português como "supertradução" (LEE-JAHNKE; DELISLE; CORMIER, 2013, p. 106), é associada à tendência deformadora do "alongamento" (BERMAN, 2007, p. 51-52); já a "explicitação" ("explicitation”) é, segundo Berman (2007, p. 51), uma das formas da "clarificação". Por fim, a "normalização" ("normalisation"), embora não citada nessa obra bermaniana, parece se aproximar da tendência deformadora da "homogeneização", que "[...] consiste em unificar em todos os planos o tecido do original, embora este seja originalmente heterogêneo" (BERMAN, 2007, p. 55). O contorno geral do termo pode ser aferido com base no conceito de normalization, em inglês, presente por exemplo na Routledge Encyclopedia of Translation Studies (BAKER; SALDANHA, 2020, p. 379).
} 
coletividade, de confiança ou desconfiança perante a língua ou as línguas que ela utiliza" e, nas obras mais recentes, como uma busca e uma prática de colocação em Relação das línguas -, mas que se vale de um questionamento e de um modo de agir pessoais, com vistas à construção de sua própria poética. A tradução assume cada vez mais, em seu discurso, uma importância primordial e se inscreve numa dimensão inédita - a saber, o Mundo-Todo ${ }^{8}$. Eis por que me pareceu interessante interrogar Édouard Glissant a respeito desse assunto que a crítica talvez ainda não tenha pesquisado de maneira suficiente.

Em Introduction à une poétique du divers (Glissant, 1995b; Introdução a uma poética da diversidade, 2005a), o senhor faz um verdadeiro elogio da tradução e atribui a ela um lugar central em sua poética, pois ela seria, cito, "uma verdadeira operação de crioulização", uma "arte da vertigem e da salutar errância", "uma das espécies mais importantes desse novo pensamento arquipelágico" 9 . Ora, eu gostaria muito que o senhor aprofundasse essas afirmações. Qual é, então, segundo o senhor, o desafio da tradução hoje? Ou, dito de outro modo, "a tarefa do tradutor", para retomar a célebre expressão de Walter Benjamin?

Édouard Glissant: 0 que acredito é que nós refletimos sobre a situação das línguas e, quando chegamos à questão das traduções, esquecemos tudo o que havíamos aprendido ou descoberto. Quando se fala em tradução, em geral, falase do que confirma ou do que ameaça uma língua, se podemos dizer assim, em sua situação e em seu próprio ser. 0 ser da língua parece ser glorificado ou ameaçado pela operação da tradução. Anteriormente, é o que se resumia dizendo que a tradução é uma traição do texto original. Sempre. Isso queria dizer que era praticamente impossível devolver o ser da língua original em outro sistema, em uma outra equação linguística, e se considerava que uma boa tradução era uma tradução que chegava a realizar esse milagre de exprimir,

\footnotetext{
${ }^{8}$ Trata-se da noção de "Tout-Monde", crucial na obra mais tardia de Glissant, haja vista os títulos de Tout-Monde (1993), que ele intitula nessa conversa um "livro de imaginário", e do ensaio Traité du Tout-Monde (1997b). Em português, prefiro a solução invertida "Mundo-todo", que mantém a ideia de totalidade planetária evitando uma confusão com a expressão "todo mundo", no sentido apenas de um grupo extenso de pessoas, que em francês corresponderia a "tout le monde".

9 Sempre que possível, utilizei as traduções de Glissant já publicadas em português. No caso dessas citações, extraídas de Glissant (2005a, p. 56), precisei adaptar o fragmento final.
} 
numa outra língua, o que tinha sido expresso antes numa primeira língua. Apesar das opacidades entre as línguas. Eu não acredito absolutamente nisso. Não acredito que o ser da língua, hoje, seja glorificado ou ameaçado pela tradução, porque esquecemos que o que nos interessa, hoje, nas línguas é, claro, o ser da língua, mas também a relação da língua, isto é, a relação da língua com todas as línguas possíveis. Toda língua tem relações com outras línguas histórica ou geograficamente próximas, isso é certo, mas eu penso que, hoje, toda língua tem relações com todas as línguas do mundo. Dito de outro modo, o que é interessante nas línguas é, desde o início, o nexo com outras línguas. E me parece que a relação não tenta, apenas, reproduzir, numa outra língua, o ser de uma língua primeira, mas que ela tenta descobrir os esquemas de funcionamento da relação de toda e qualquer língua com toda e qualquer língua. É por isso que eu penso que a tradução, hoje, é um elemento primordial de exercício literário, porque ela tem uma função que não é uma função comprimida, muito especializada tecnicamente, mas que é uma função poética geral do nexo de toda e qualquer língua com toda e qualquer língua. Por conseguinte, a tradução se torna uma arte em si, com seu campo que é, não o campo das línguas, mas o campo do nexo das línguas. O campo da relação das línguas. É por isso que eu penso que a tradução, em breve, será uma arte específica. E creio que isso levará o tempo que for necessário, mas que um dos elementos cada vez mais importantes da vida linguística, hoje, será a expressão de uma realidade, ou de uma verdade, ou de um sonho, ou de uma utopia etc., não apenas numa dada língua, mas também no nexo de várias línguas com várias línguas. Eis por que, a meu ver, a tradução está se tornando uma arte primordial.

Enquanto o senhor falava, eu estava refletindo sobre uma coisa. É evidente que o senhor propõe ultrapassar, por fim, a dialética traição-fidelidade para a tradução, e nisso estou em pleno acordo, pois não há naquilo qualquer interesse, segundo me parece, para a reflexão sobre a tradução. Escutando- falar de relação, eu pensava na maneira de declinar suas afirmações na prática. 0 senhor sabe, o tradutor sempre se interroga sobre como fazer 
passar certas coisas em outra língua. 0 desafio da tradução é também o de fazer passar um outro imaginário...

Édouard Glissant: Mas aí não são problemas de relação, são problemas de equivalência. Não é a mesma coisa, pois os problemas de equivalência, podese resolver com truques. Dispõe-se de meios técnicos para resolver certas questões, com pequenas ferramentas ou grandes ferramentas de transformação nas línguas. Isso são problemas de equivalência. O problema da relação entre as línguas é diferente, porque exige do tradutor, não que ele tenha pequenos truques por meio dos quais vai tentar fazer equivalências entre língua $x$ e língua y, mas exige que ele tenha imaginário. Não truques. Imaginário. Uma concepção real do que se passa, naquele momento, entre as duas línguas, é certo, mas entre duas línguas em presença das outras línguas. 0 que é de fato uma dimensão nova, veja só. Em outras palavras, a equivalência, a solução de equivalência é válida para todo tradutor, mas para todo tradutor tomado isoladamente, contanto que ele viva sua aventura pessoal entre duas línguas. Ao passo que a solução de estabelecer um nexo é válida para todos os tradutores, contanto que eles exerçam, não entre duas línguas somente, mas entre todas as línguas e todas as línguas e, consequentemente, não é a mesma coisa. Quando um documento econômico é traduzido de uma língua para outra, há relações de equivalência, o que faz com que sejam encontrados truques para exprimir aproximadamente, o mais próximo possível, o primeiro documento no segundo. Podem-se fazer textos jurídicos, textos econômicos, textos etc., e neles encontrar os truques. É a tradução tecnicamente compreendida como uma arte da equivalência. Mas quando traduzimos o inefável, quando traduzimos o indizível, os truques de equivalência não são mais suficientes, é preciso um imaginário do tradutor que invente algo de novo no que diz respeito aos truques de equivalência de uma língua a outra.

O que eu queria dizer é que estava pensando na maneira pela qual poderíamos traduzir o que o senhor diz a respeito da relação em função da prática da tradução... 
Édouard Glissant: Sim, mas isso é o imaginário ou o engenho ${ }^{10}$ do tradutor que vai encontrar, não há regras. Não posso dar regras de tradução. Se eu ditar regras de tradução, são regras de equivalência, e não regras de imaginário, isso é óbvio. Eu não posso me colocar no lugar de um tradutor. Posso ser, em contrapartida, um tradutor, se estiver diante de um texto em uma língua outra que aquela que eu falo, e por minha vez me tornar um tradutor para ter o imaginário dessa nova relação. Mas não posso ditar regras. Se eu ditar as regras de relação na tradução, isso não vai ter nada de válido na tradução. É que a tradução é uma mecânica, e para mim a tradução não é uma mecânica.

E nisso estamos em pleno acordo. Eu penso mesmo que a noção de equivalência, no que concerne às línguas, não quer dizer nada. Penso que, às vezes, não se chega a encontrar equivalentes mesmo quando se traduzem textos jurídicos ou econômicos...

Édouard Glissant: Não há equivalência, mas é o que se procura. É esse o problema...

Sim, é uma miragem.

Édouard Glissant: É uma miragem, mas é o que se procura. É realmente preciso que haja algumas equivalências de termos. Quando se fazem tratados internacionais - a história, aliás, está abarrotada de exemplos -, basta que se mude uma palavra num tratado para que todo o tratado seja diferente. Logo, o que se procura é a equivalência, seja ela possível ou não. Não se procura a relação, é isso o que quero dizer.

Eu pensava, no que diz respeito à relação, que poderíamos considerar a própria prática da tradução entre duas línguas como uma tentativa de reproduzir certa relação dentro da língua. Penso especialmente na literatura. Quando traduzimos literatura, se traduzimos grandes autores,

\footnotetext{
10 "Engenho" traduz, em todas as ocorrências deste texto, a palavra "génie", que geralmente corresponde a "gênio"/"genialidade", mas também pode ser traduzida como "engenharia". Minha solução busca evitar, ao mesmo tempo, a concepção demasiado romântica da primeira possibilidade e o caráter excessivamente frio, mecânico, da segunda. Isto, porque a noção de "engenho", na tradição lusófona (e sobretudo no Barroco, tido como arte engenhosa), parece aliar com justa medida a premência da invenção - não necessariamente "original" no sentido romântico - e o rigor da técnica. Vale notar que, quase ao final da conversa, Glissant refuta a aproximação com o pensamento romântico alemão proposta por Pattano.
} 
nos encontramos diante de uma língua estrangeira e nos encontramos diante da linguagem de um autor que se coloca à margem de sua língua, ou de suas línguas, de escrita. E o desafio, a aposta da tradução é justamente de chegar ou de tentar adivinhar essa relação entre a língua de escrita e a língua ou linguagem do escritor. E de considerar uma possibilidade de tradução, ao buscar outras relações.

Édouard Glissant: Ok, estou de acordo. Sem problemas.

Ainda na Introduction à une poétique du divers, o senhor definia a tradução a partir de fórmulas tão cativantes quanto verdadeiras, acho eu. 0 senhor falava, em especial, da tradução como uma arte da fuga e da renúncia ${ }^{11}$. Uma renúncia que não seria perda, mas beleza, pois se trataria, cito, “[d]a parte de si mesmo que se abandona, em toda e qualquer poética, ao outro" (Glissant, 2005a, p. 57). A questão que coloco é, portanto: será que a renúncia inerente (e necessária) a toda tradução não é ambivalente e, assim, diria respeito a si mesmo, tanto quanto ao outro? E, ao dizer isso, penso numa proposição de Paul Ricoeur. Talvez pudéssemos resumir uma tal ambivalência na fórmula que Ricoeur propõe, a partir de Freud, em " 0 paradigma da tradução" (“Le paradigme de la traduction”, Ricoeur, 2004; 2011, p. 33-58). Com efeito, ele afirmava, nesse breve ensaio, a necessidade para o tradutor de realizar um "trabalho do luto" ("travail de deuil", Ricoeur, 2011, p. 27), que tenha por objeto o ideal da tradução perfeita ou, se o senhor preferir, da traduzibilidade absoluta.

Édouard Glissant: Não concordo absolutamente. O que a senhora diz que Ricoeur diz, é renunciar a uma parte da possibilidade técnica de traduzir. Não é disso que eu falo. Ele diz, renunciamos de início ao sonho de uma tradução perfeita e, consequentemente, começamos uma tradução imperfeita, mas o fato de pensá-la imperfeita vai levar à tradução mais perfeita possível. É isso que ele diz. Logo, a renúncia é um luto técnico, de prática. A mim, não me

\footnotetext{
11 "Un art de la fugue et du renoncement". Vale notar, aqui, a sutileza dos dois termos: "fuga" ("fugue", diferente de "fuite") é uma das principais figuras do Barroco; já "renúncia" pode atualizar uma leitura sutil do ensaio "A tarefa do tradutor" ["Die Aufgabe des Übersetzers"], de Walter Benjamin (2011 [1921]), em que o substantivo alemão Aufgabe pode significar tanto "tarefa" como "renúncia".
} 
interessa o que o tradutor faz, porque o tradutor pode ter o engenho de uma completude imediata sem luto, mas ele pode ter também, como diz Ricoeur, à força de renunciar a uma tradução perfeita, o engenho de chegar à tradução mais perfeita possível. Mas isso não é, segundo me parece, o que eu falava no texto que a senhora evocou. 0 texto que a senhora evocou fala da possibilidade de renunciar a uma concepção da relação entre duas línguas para imaginar, encontrar, inventar uma nova relação entre essas duas línguas que ainda não havia sido percebida por ninguém. É o que chamo de inventividade ou de criatividade do tradutor. Logo, isso não tem muito a ver com o que Ricoeur diz, a meu ver.

Então poderia me explicar o que seria, para o senhor, a renúncia na tradução?

Édouard Glissant: A renúncia, eu a explico pelo fato de que começamos a tomar conhecimento de que o ser de uma língua não é exclusão do ser de uma outra língua. E é a isso que renunciamos, a essa crença de que o ser de uma língua é uma árvore, e começamos a compreender que o ser de uma língua é um rizoma. Portanto, essa renúncia é uma renúncia a um absoluto linguístico, para entrar cada vez mais num relativo linguístico.

Volto um instante a Ricoeur para colocar uma questão que me parece muito interessante e que foi apenas esboçada pelo próprio Ricoeur em "O paradigma da tradução". Ricoeur atribui à tradução uma função ética que ele nomeia "hospitalidade linguageira" ${ }^{12}$. Em L'Épreuve de l'étranger (1984; A prova do estrangeiro, 2002, p. 16-17), Antoine Berman já enxergava a dimensão ética do traduzir e falava dela nestes termos: "[a] própria visada da tradução - abrir no nível da escrita uma certa relação com o Outro, fecundar o Próprio pela mediação do Estrangeiro - choca-se de frente com a estrutura etnocêntrica de qualquer cultura, ou essa espécie de narcisismo que faz com que toda sociedade deseje ser um Todo puro e não misturado. Na tradução, há alguma coisa da violência da mestiçagem. [...] Qualquer cultura desejaria ser suficiente em si mesma para, a partir

12 "hospitalité langagière". A tradução brasileira (Ricoeur, 2011, p. 30) traz "hospitalidade linguística", solução que preferi evitar. 
dessa suficiência imaginária, ao mesmo tempo brilhar sobre as outras e apropriar-se de seu patrimônio. A cultura romana antiga, a cultura francesa clássica e a cultura norte-americana moderna são exemplos marcantes disso.../ Ora, a tradução ocupa aqui um lugar ambíguo. Por um lado, ela se submete a essa injunção apropriadora e redutora, constitui-se como um de seus agentes. 0 que acaba por produzir traduções etnocêntricas, ou o que podemos chamar de 'má' tradução. Mas, por outro lado, a visada ética do traduzir opõe-se por natureza a essa injunção: a essência da tradução é ser abertura, diálogo, mestiçagem, descentralização. Ela é relação, ou não é nada". Aqui está minha questão: será que o senhor partilha dessa ideia da tradução como paradigma ético?

Édouard Glissant: Não, de maneira alguma. Não partilho da ideia da tradução como paradigma ético, porque me parece que a poética da tradução, justamente, é uma poética que informa processos de relação, e não conteúdos. Ora, considerar a tradução, mesmo em seu processo de transferência, como uma abertura ao outro e como uma possibilidade de mestiçagem etc. é considerar, de um lado, que os nexos com o outro são, de partida, nexos de conteúdo - porque a ética é isso, a reflexão sobre um conteúdo, o que não me parece justo ou, em todo caso, o que não me parece suficiente. $E$, de outro lado, é considerar que a translação na relação é justamente uma translação desse conteúdo. Ora, o que é interessante na relação não é a translação do conteúdo: é a translação das poéticas, isto é, a translação das imagens formais da língua. E a imagem formal da língua não tem moral. A imagem formal da língua não tem princípios. Não é o conteúdo do texto que é traduzido. É $a$ poética do texto. Quando se traduz o conteúdo do texto, cria-se um nexo mecanicista, mas não se cria relação. E o que quero dizer é que, quando se diz que a tradução é um exercício de estabelecer nexos com o outro - isso é verdadeiro, mas não é um exercício de estabelecer nexos com o outro no nível de uma ética. E não é o exercício de estabelecer nexos com o outro nesse nível que vai acarretar uma mudança num conteúdo, porque a ideia que a senhora desenvolve é que o nexo estabelecido entre duas línguas vai desencadear uma mudança de conteúdo, por exemplo a mestiçagem, etc., etc., etc. Mas a 
mestiçagem é interessante, não por seu conteúdo, mas pelas poéticas de sua forma; e, se não entendemos isso, nós permanecemos no antigo... Mudo de ética, sim, mas eu não mudo de mundo no qual a ética é soberana, mudo simplesmente de ética, e a ética permanece sendo soberana, ao passo que, na relação, a ética não é soberana. Se a relação não é suficiente para assegurar o nexo, a mestiçagem, isto ou aquilo, sem a ética, é que a relação não é boa. É isso o que quero dizer. No que a senhora diz, não se alterou o princípio fundamental do nexo - isto é, que o princípio fundamental do nexo é a ética -, mas eu não acredito que a ética seja possível fundamentalmente. Acredito que a relação não tem moral, cada indivíduo forja e cria para si sua própria moral.

Não há um princípio moral da relação, não há uma ética pela qual se passe disto para aquilo. $\mathrm{E}$, consequentemente, não posso estar de acordo com essa proposição. Não acredito mais na potência central da ética. A ética é uma poética que vale para cada um de nós, homens no mundo moderno, e não uma potência que vale para uma comunidade ou para uma fé, ou para uma religião, ou... Podemos ter a mesma religião e não ter a mesma ética. Portanto, penso que o que se disse lá não me concerne, porque está dito do ponto de vista de uma concepção, de uma crença da qual não partilho mais.

\section{E não a considera nem mesmo viável... Eu consigo enxergar o que o senhor diz: na Poética da Relação, não há nenhuma ética que valha...}

Édouard Glissant: A princípio. Quero dizer, se há um sistema de Relação que se liga a uma ética, pois bem, nada mudou, isso não é um sistema de Relação. Do mesmo modo que, segundo Deleuze, um rizoma não tem princípio de genealogia, o que uma árvore tem, isto é, um pai que tem um filho, que tem um filho, que tem um filho... O rizoma não é isso, isso é a árvore. 0 rizoma é a extensão ${ }^{13}$ na qual não sabemos mais quem é o filho de quem...

\footnotetext{
13 "étendue": trata-se de uma noção/imagem presente, por exemplo, no subtítulo de Philosophie de la Relation. Poésie en étendue, e que chama a atenção para uma longa dimensão horizontal, oposta à profundidade ("profondeur"), como uma representação da busca por um conhecimento topológico - ao rés do chão - na totalidade-mundo contemporânea. Daí a proximidade com o célebre conceito de "rizoma", proposto por Deleuze \& Guattari (2011), e citado frequentemente por Glissant.
} 
Então o senhor renuncia a considerar, digamos, a questão da dialética bemmal, o senhor a exclui de sua reflexão?

Édouard Glissant: Não renuncio a isso, mas o bem e o mal são decididos pelas pessoas, e não pela comunidade global. É certo que há bem e mal, mas eu tenho uma concepção do bem que não é a sua, e minha concepção do mal não é aquela do senhor Bush... Podemos ter as mesmas concepções, mas só as temos individualmente, não as temos comunitariamente.

Se entendi direito, o senhor não acredita mais, digamos, na possibilidade ou, talvez, na validade de sistematizar as questões ligadas à ética.

Édouard Glissant: Absolutamente.

Em Tout-Monde (Glissant, 1993), seu romance de 1993 no qual descobri belíssimas imagens da tradução, há uma figura curiosa, um personagem inquieto e contraditório que tenta ultrapassar - ou talvez apenas viver com - seu tormento de linguagem, assumindo, arrisco dizer, a tradução como condição existencial. Estou falando, evidentemente, do triplo Anestor: Anestor Masson (o antilhano), Anestor Klokoto (o zairense) e Anestor Salah (o árabe). Esse homem vive, ao mesmo tempo, três vidas diferentes e, em cada uma delas, esforça-se para falar uma língua outra em relação ao francês, uma língua que seria aquela de seu país de origem. Eu pergunto: não poderíamos ler essa história ${ }^{14}$ como uma tradução narrativa de sua poética da Relação?

Édouard Glissant: Num livro de imaginário como Tout-Monde, que não é um romance, que não é uma história, que é justamente uma obra de imaginário e de mescla e de mistura, os episódios de relação com o real são evidentemente paralelos aos episódios de relação com o poético, com o imaginário. A relação orgânica dos personagens corresponde à relação poética das ideias, isso é óbvio. Logo, é por isso que, naquilo que eu escrevo, não há separação entre as obras de construção do imaginário e as obras de construção de poética, está tudo misturado. Logo, a pergunta é óbvia...

\footnotetext{
14 "Récit", termo francês que é habitualmente traduzido como "narrativa". Nesse contexto, utilizo "história", para evitar repetição imprecisa com a expressão subsequente, "tradução narrativa" ("traduction narrative").
} 


\section{A pergunta é sem dúvida banal, era para fazer o senhor falar desse personagem...}

Édouard Glissant: Falar de um personagem é acreditar que existe uma arte sistêmica, por exemplo, do romance, o que eu não acredito de maneira alguma, porque o personagem, de início, pode se impor... Se releio um texto que escrevi, o personagem pode se impor para mim de uma outra maneira, diferente daquela do momento em que o escrevi, isto é, eu mudo relativamente ao personagem.

O personagem pode se impor de uma outra maneira relativamente a dois leitores possíveis. 0 personagem pode se impor de maneira distinta relativamente a uma infinidade de leitores possíveis. $E$, como consequência disso, do mesmo modo que não há, que não havia agora há pouco uma receita prática para passar de uma teoria da relação na tradução para traduções reais, assim também não há nesse caso um princípio do personagem que seja dado de uma vez por todas. $E$, do mesmo modo que não há uma ética que seja dada de uma vez por todas para todo mundo, assim também não há uma visão. Pessoas que me conhecem bem tem visões deveras diferentes dos personagens de ToutMonde. Algumas delas me dizem coisas sobre os personagens de Tout-Monde que me deixam estupefato, porque eu não havia pensado nisso. A partir desse momento, não estou qualificado para descrever os personagens, porque - é verdade - tenho amigos que falam dos personagens de Tout-Monde melhor que eu. Porque eles encontram coisas nas quais eu não pensei, ao escrever o personagem, mas nas quais pensei dentro da relação imaginária. Esse pensamento estava por trás, e é o leitor que me faz pensar que havia esse pensamento. E, consequentemente... É por isso que, no exercício de perguntaresposta, eu sou tão relutante. Porque, com frequência, é uma duplicação, o que não é verdadeiramente... Não é culpa de quem pergunta, não é culpa de quem é questionado, é o princípio mesmo que é...

Talvez valesse mais a pena dialogar...

Édouard Glissant: Sim, vale mais a pena dialogar ou vale mais a pena trocar monólogos, porque na pergunta... Aquele que pergunta coloca a questão em função de uma resposta que espera... 
Sim, sem dúvida alguma. De fato, para retornar a Anestor, o que me parece muito interessante nele é que seu conflito linguageiro se manifesta numa tensão tradutória nutrida, me parece, de uma grande confiança na possibilidade da convergência das línguas.

Édouard Glissant: Convergência, não. Relação. Relação das línguas. Convergência é redutor.

Na segunda seção do Discours antillais (Glissant, 1981), o senhor afirma que uma das primeiras inquietações ${ }^{15}$ de seu trabalho de produção em literatura consiste na elaboração de uma linguagem que se coloca no limite do escrever e do falar, de uma linguagem que chega a uma "síntese" - cito “da sintaxe escrita e da rítmica falada, do 'adquirido' da escrita e do 'reflexo' oral, da solidão da escrita e da participação no cantar comum" 16 (Glissant, 1981, p. 256). E o senhor apresenta seu procedimento de escritor não como pessoal, mas como parte de um movimento comum, aquele do "romance das Américas" 17, cuja linguagem se caracterizaria por uma ligação bastante atormentada não apenas entre a escrita e a oralidade, mas igualmente, no caso das Antilhas francesas, entre uma língua francesa a ser desestruturada e uma língua crioula a estruturar. Poderíamos assim pensar, e me corrija se estiver errada, que o senhor concebeu seu trabalho como uma prática de tradução particular, que vai além do ato de tradução implicado em todo ato de escrever (isto é, a transposição, a colocação em palavra de uma ideia, de uma intuição, de uma história), pois ela nasce de uma atenção à crioulização, de colocação em Relação dos múltiplos dados que concorrem para o florescimento identitário.

Édouard Glissant: Sim, estou de acordo.

\footnotetext{
15 "Aqui, "inquietações" traduz "soucis". Mais à frente, nesta fala da entrevistadora, o mesmo vocábulo francês é vertido de modo diverso em "pois ela nasce de uma atenção à crioulização" ("car elle naît d'un souci de créolisation”) - a alternância das soluções se dá, aqui, pela necessidade de adequação ao contexto.

16 "J'évoque une synthèse, synthèse de la syntaxe écrite et de la rythmique parlée, de l' 'acquis' d'écriture et du 'réflexe' oral, de la solitude d'écriture et de la participation au chanter commun". Tradução minha.

17 Trata-se da categoria de "roman des Amériques", explorada em Le discours antillais (Glissant, 1981).
} 
Eu estava me perguntando se o que o senhor diz nesse texto mudou muito desde então. Le discours antillais remonta a uma certa época de sua produção...

Édouard Glissant: Sim, isso mudou, porque há um lado bilateral - oral-escrito - ultrapassado pelo que eu penso de uma poética da Relação. A poética da Relação nunca é bi-alguma coisa, ela é sempre múltiplo-alguma coisa. E além do mais, desde que escrevi o Discours, a oralidade entrou muito na escrita, e a escrita retornou muito à oralidade. A situação mudou muito e, consequentemente, a Relação não é mais tão binária. Há muitos outros elementos que entraram em jogo desde então. Por exemplo, os elementos da energia da linguagem, ligados à energia do mundo... Não é que isso não seja mais verdadeiro, ainda é verdadeiro, mas não é mais tão sistemático. Porque a oralidade, se posso dizer assim, entrou de tal modo na escrita, que ela não tem mais necessidade de apontá-la com o dedo.

E o senhor fala em geral ou apenas relativamente ao romance das Américas, como o chamava...

Édouard Glissant: Em geral.

Quando a li, essa passagem me impressionou, porque me fez pensar nos românticos alemães. 0 senhor sabe, na época do Romantismo, a tradução era muito importante na Alemanha. Havia muitos poetas que traduziam e, entre eles, havia poetas, como Goethe, que diziam querer, ao traduzir, germanizar a outra língua ou vice-versa, ligar a língua deles à língua estrangeira, sabe... E eu encontro um pouco disso em suas palavras, quando o senhor diz querer desestruturar a língua francesa e estruturar a língua crioula...

Édouard Glissant: Isso evoluiu desde então, não temos mais necessidade disso. Os processos se interpenetraram de tal maneira, que não é mais interessante, hoje, dizer "quero desestruturar a língua francesa".

Era o que dizíamos no início da... "francofonia literária", digamos para abreviar, ainda que normalmente eu evite empregar esse termo incômodo... Édouard Glissant: Sim. 
No Discours antillais, o senhor estabelece, ademais, um paralelo muito interessante, a meu ver, entre as condições socioeconômicas e políticas de um país e as línguas que são faladas nele, sendo que os nexos entre as línguas exemplificam as primeiras, isto é, as condições socioeconômicas. No que concerne às Antilhas francesas, o senhor descrevia o crioulo como uma língua "em suspensão", que não produz nada e nada saberia produzir, até que seja assumida por sua coletividade. Se o crioulo parece infecundo e sob risco de desaparição, em benefício da língua oficial, esta serve somente para consumir. 0 que eu gostaria de saber é, logo de início, se o senhor avalia suas análises da época como ainda atuais e pertinentes, isto é, se de acordo com o senhor, alguma coisa mudou desde essas formulações.

Édouard Glissant: Mesma resposta. Não é mais pertinente, porque isso se tornou uma verdade comum, isso se tornou um lugar comum. E não é mais pertinente, porque percebemos que, no Mundo-Todo, todas as situações podem intervir: sociedades desestruturadas com a expressão muito estruturada, sociedades muito estruturadas com uma ausência de expressão etc. Em todas as partes do mundo, isso repercute de maneira rizomática e cada vez diferente, e é por isso que muitas ideias que estavam no Discours antillais ou mesmo em Poétique de la Relation (Glissant, 1990; Poética da Relação, 2011) - que eram ideias operatórias, que serviam para fazer alguma coisa, para propor... - não são mais ideias de Tout-Monde ou do Traité du Tout-Monde (Glissant, 1997b), porque justamente a própria concepção de Mundo-Todo tornou essas ideias... Essas ideias permitiram a concepção do Mundo-Todo, mas a concepção do Mundo-Todo tornou essas ideias, não inúteis, mas inúteis de exprimir.

Assim, relativamente, por exemplo, a essa outra questão que o senhor enfrentava em Le discours antillais, a questão da luta pela sobrevivência, digamos, de cada língua particular... Esse problema não se coloca mais no Mundo-Todo?

Édouard Glissant: Não, é que uma vez que o colocamos como problema, está encerrado. Não precisamos colocá-lo uma segunda vez, porque... Bom, por exemplo o crioulo. Se existem crioulistas que batalham pelo crioulo, tanto melhor. Mas se tivermos uma ideologia da luta pelo crioulo, nós paramos a 
progressão do crioulo em lugar de ajudá-lo, porque o crioulo não suporta a ideologia. Eis por que os crioulistas são muito inconscientes, pois pretendendo oferecer uma ideologia para a defesa do crioulo, eles dão um stop ${ }^{18}$ no crioulo. Sim, nós nunca impomos uma língua.

Édouard Glissant: Não.

18 "stoppent": a solução tende a soar mais coloquial em português que em francês, já que o verbo "stopper", dicionarizado, data de meados do século XIX, segundo o dicionário do CNRTL. Não quis apagar, todavia, a ironia glissantiana de incluir uma palavra de raiz evidentemente inglesa (o verbo to stop) no contexto da discussão sobre a defesa de línguas ameaçadas, como o crioulo. Conforme Glissant argumenta em diversas ocasiões, a defesa de uma língua deve englobar a defesa de todas as línguas, pois "[...] não salvaremos uma língua do mundo deixando morrer as demais" (Glissant, 2005a, p. 50), e isso repercute no próprio inglês (que ele costuma chamar de anglo-americano), ameaçado de diluição numa língua supostamente universal. A essa primeira camada se soma uma segunda, de que "[a] subversão vem da crioulização (linguística), e não dos crioulismos" (2005a, p. 143), ou seja, a ironia discursiva consiste em empregar uma expressão de origem inglesa - que testemunha o processo, a crioulização quando se espera, talvez, que o pensador recue para uma defesa da pureza da língua crioula, utilizando o produto acabado, o crioulismo. 


\section{Referências bibliográficas}

amaral, Henrique Provinzano. Praia negra, praia ardente: uma leitura do oral em Poétique de la Relation, de Édouard Glissant. Dissertação (Mestrado em Língua e Literatura Francesa) - Faculdade de Filosofia, Letras e Ciências Humanas, Universidade de São Paulo, São Paulo, 2019.

Benjamin, Walter. "A tarefa do tradutor". In: Escritos sobre mito $e$ linguagem. Org. Jeanne Marie Gagnebin. Trad. Susana Kampff Lages, E. Chaves. São Paulo: Editora 34, 2011, pp. 101-119.

BAKER, Mona; SALDANHA, Gabriela (Org.). Routledge Encyclopedia of Translation Studies. New York: Routledge, 2020.

BERMAN, Antoine. L'Épreuve de l'étranger: culture et traduction dans l'Allemagne romantique. Paris: Gallimard, 1984.

- A prova do estrangeiro. Trad. Maria Emília Pereira Chanut. Florianópolis: EDUSC, 2002.

- A tradução e a letra ou o albergue do longínquo. Trad. Marie-Hélène Catherine Torres, Mauri Furlan e Andréia Guerini. Rio de Janeiro: 7Letras/PGET, 2007.

DeleUze, Gilles; GUATTARI, Félix. Mil platôs: capitalismo e esquizofrenia 2, vol. 1. Trad. Ana L. de Oliveira, Aurélio G. Neto e Celia P. Costa. São Paulo: Editora 34, 2011.

GLISSANT, Édouard. Le discours antillais. Paris: Seuil, 1981.

. Poétique de la Relation. Paris: Gallimard, 1990.

. Tout-Monde. Paris: Gallimard, 1993.

"Traduire: relire, relier (Conférence inaugurale)". In: Onzième assises de traduction littéraire, $\mathrm{n}^{\circ} 11$, Arles. Paris: Actes Sud, pp. 45-46, 1995a.

- Introduction à une poétique du Divers. Montreal: Presses de l'Université de Montreal, 1995b.

"Les nouvelles données de l'écriture". In : Société et littérature antillaise aujourd'hui. Perpignan, França: Cahiers de l'Université de Perpignan, $\mathrm{n}^{\circ} 25$, pp. 109-110, 1997a.

- Traité du Tout-Monde. Paris: Gallimard, 1997b.

Introdução a uma poética da diversidade. Trad. Enilce do Carmo Albergaria Rocha. Juiz de Fora: Editora UFJF, 2005a.

. La Cohée du Lamentin. Paris: Gallimard, 2005b.

. Philosophie de la Relation. Poésie en étendue. Paris: Gallimard, 2009. 10 mai. Mémoires de la traite negrière, de l'esclavage et de leurs abolitions. Paris: Galaade/Institut du Tout-Monde, 2010a.

. L'imaginaire des langues. Entretiens avec Lise Gauvin (1989-2009).

Paris: Gallimard, 2010b. 
La terre, le feu, l'eau et les vents. Une anthologie de la poésie du Tout-Monde. Paris: Galaade, 2010c.

2011.

Poética da Relação. Trad. Manuela Mendonça. Porto: Sextante Editora,

O pensamento do tremor - La Cohée du Lamentin. Trad. Enilce do Carmo Albergaria Rocha e Lucy Magalhães. Juiz de Fora: Editora UFJF, 2014.

LEE-JAHNKE, Hannelore; DELISLE, Jean; CORMIER, Monique (Org.). Terminologia da tradução. Trad. Álvaro Faleiros e Claudia Xatara. Brasília: Editora Universidade de Brasília, 2013.

RICOEUR, Paul. Sur la traduction. Paris: Bayard, 2004.

- Sobre a tradução. Trad. Patrícia Lavelle. Belo Horizonte: Editora

UFMG, 2011. 